\title{
Problems and outlook for marketable wheat grain production
}

\author{
Elena Meleshkina ${ }^{1}$, Olga Bundina $^{1 *}$ \\ ${ }^{1}$ VNIIZ - Branch of Gorbatov Research Center for Food Systems \\ 11, Dmitrovskoe Sh., Moscow, 127434, Russia
}

\begin{abstract}
In recent years, Russia has made considerable advances in the production and export of grain. Grain production, primarily wheat, is the driver of the country's economic growth. At the same time, wheat grain has a multipurpose use, it is a valuable multifunctional primary product for obtaining a wide range of production with high added value, consumed by many economic sectors. A paradoxical situation has developed: Russia is the world's largest exporter of grain - primary product, and is acutely dependent on imported products of its processing. Therefore, the outlook for the wheat grain production development is associated with the expansion of production of wheat grain processing products, with its advanced processing and export of products with high added value. The development of advanced grain processing will increase the profitability as of agribusiness, the processing industry in general, as of exporters.
\end{abstract}

Key words: grain, wheat, domestic consumption, export, advanced processing.

\section{Introduction}

In recent years, Russia has made impressive progress in the production and export of grain. For the fifth year in a row, our country becomes a world leader in exports. Wheat grain is the basis commodity of world trade, the key agricultural crop in Russia, mainly exported abroad. The wheat planted area in 2020 amounted to $36.8 \%$ of the total planting acreage and $61.4 \%$ of the total acreage under cereal and pulse crops, the share of wheat in grain exports is about $80 \%$. From 1990 to 2020 grain exports significantly increased - 24.4 times, and from 2015 to 2020 wheat grain exports almost doubled. However, wheat grain is not only the basis commodity of world trade and Russian export, at the same time it is a valuable primary product, from which a wide range of production with high added value is obtained. «Nowadays trading in just grain itself is equal to trading in oil. It is necessary to develop more economically profitable processing industry.» - emphasized the Deputy Chairman of the Government of the Russian Federation A.V. Gordeev at the XX International Grain Round in June 2019.

The purpose of the study is to identify problems and determine the development outlook for marketable wheat grain production and use.

\section{Materials and methods}

The grain complex of Russia is a complex system for research. Therefore, it is advantageous to use a systemsynergetic approach. It proposes to study the grain complex in dynamics along the entire value chain (from grain production to export).

\section{Results and Discussion}

The main indicators, characterizing the development of the grain complex of Russia, are presented in the table. In general, it has a positive trend. From 1990 to 2020, the gross harvest of grain in general and of wheat increased by $14.3 \%$ and $73.2 \%$, respectively. The grain complex developed most intensively from 2015 to 2020. During this period, the compound feed industry increased by $24.2 \%$, the wheat gluten production - by $34.2 \%$, and the export of wheat grain increased by $80.7 \%$. At that, the share of wheat in grain exports is about $80 \%$ in recent years.

Wheat grain is a primary product for multipurpose use, but in recent years, an emphasis is placed on the development of grain export at the expense of its processing and the development of its domestic consumption. So, from 1990 to 2020, the volume of grain processed into flour, groats, compound feed and other products reduced by almost $57 \%$, which is 40.9 million tonnes, that is, by an amount almost equal to the volume of grain exports. At that, the compound feed industry is growing, but the demand for it is not so high, as the cattle population in 2019 reached its historical low of 18.1 million heads (in the most difficult year of the $2^{\text {nd }}$ World War - 1942, the cattle population was 18.8 million heads). From 2015 to 2019 , the production of wheat and wheatrye flour decreased by $5.5 \%$. During the same period, flour exports had a small volume despite an increase of $17.3 \%$, especially in comparison with the Turkish export of flour, to a considerable extent produced from Russian grain. [3]

*Corresponding author: boi888@mail.ru 
Table. Main indicators of production, processing and export of grain, including wheat*[1-2]

\begin{tabular}{|c|c|c|c|c|c|c|c|c|c|}
\hline Indicators $\quad$ Years & 1990 & 1995 & 2000 & 2015 & 2016 & 2017 & 2018 & 2019 & 2020 \\
\hline $\begin{array}{l}\text { Gross harvest, } \mathrm{mln} \mathrm{t} / \% \text { : } \\
\text { - cereal, pulse crops - total, incl. } \\
\text { wheat }\end{array}$ & $\begin{array}{l}\frac{116.7}{100 \%} \\
\frac{49.6}{100 \%}\end{array}$ & $\begin{array}{l}\frac{63.4}{54.3} \\
30.1 \\
60.7 \\
\end{array}$ & $\begin{array}{l}\frac{65.4}{56.0} \\
34.5 \\
69.6\end{array}$ & $\begin{array}{l}\frac{104.7}{89.7} \\
\underline{61.8} \\
124.6\end{array}$ & $\begin{array}{l}\frac{120.7}{103.4} \\
\frac{73.3}{147.8} \\
\end{array}$ & $\begin{array}{l}\frac{135.5}{116.1} \\
\frac{86.0}{173.4} \\
\end{array}$ & $\begin{array}{l}\frac{113.3}{97.1} \\
\underline{72.1} \\
145.4 \\
\end{array}$ & $\begin{array}{l}\frac{121.2}{103.9} \\
\frac{74.4}{150.0} \\
\end{array}$ & $\begin{array}{r}\frac{133.4}{114.3} \\
\underline{85.9} \\
173.2 \\
\end{array}$ \\
\hline $\begin{array}{l}\text { Grain processed into flour, } \\
\text { groats, compound feed etc., mln } \\
\text { t/\% }\end{array}$ & $\frac{94.7}{100 \%}$ & $\frac{63.1}{66.6}$ & $\frac{40.6}{42.9}$ & $\frac{48.2}{50.9}$ & $\frac{51.7}{54.6}$ & $\frac{53.3}{56.3}$ & $\frac{52.5}{55.4}$ & $\frac{53.3}{56.3}$ & $\frac{53.8}{56.8}$ \\
\hline $\begin{array}{l}\text { Wheat and wheat-rye flour } \\
\text { production, mln } \mathrm{t} / \%\end{array}$ & - & - & - & $\frac{9.1}{100 \%}$ & $\frac{9.0}{98.9}$ & $\frac{8.8}{96.7}$ & $\frac{8.8}{96.7}$ & $\frac{8.6}{94.5}$ & - \\
\hline $\begin{array}{l}\text { Compound feed production, mln } \\
\mathrm{t} / \%\end{array}$ & - & - & - & $\frac{24.8}{100 \%}$ & $\frac{26.1}{105.2}$ & $\frac{27.6}{111.3}$ & $\frac{28.9}{116.5}$ & $\frac{29.6}{119.4}$ & $\frac{30.8}{124.2}$ \\
\hline $\begin{array}{l}\text { Wheat gluten production, mln } \\
\mathrm{t} / \%\end{array}$ & - & - & - & $\frac{11.1}{100 \%}$ & $\frac{12.2}{109.9}$ & $\frac{12.8}{115.3}$ & $\frac{13.5}{121.6}$ & $\frac{14.1}{127.0}$ & $\frac{14.9}{134.2}$ \\
\hline $\begin{array}{l}\text { Exports, mln t/\%: } \\
\text { - grain - total, incl. }\end{array}$ & $\frac{2.0}{100 \%}$ & $\frac{1.0}{50 \%}$ & $\frac{1.3}{65.0}$ & $\begin{array}{l}\frac{30.7}{15.4} \\
\text { times }\end{array}$ & $\begin{array}{l}\frac{33.9}{17} \\
\text { times }\end{array}$ & $\begin{array}{l}\frac{43.3}{21.6} \\
\text { times }\end{array}$ & $\begin{array}{l}\frac{54.8}{27.4} \\
\text { times }\end{array}$ & $\begin{array}{l}\frac{39.3}{19.6} \\
\text { times }\end{array}$ & $\begin{array}{l}\frac{48.7}{24.4} \\
\text { times }\end{array}$ \\
\hline wheat & - & - & - & $\frac{21.2}{100 \%}$ & $\frac{25.3}{119.3}$ & $\frac{33.1}{156.1}$ & $\frac{44.0}{207.6}$ & $\frac{31.8}{150.0}$ & $\frac{38.3}{180.7}$ \\
\hline - flour (wheat and wheat-rye) & - & - & - & $\frac{264.8}{100 \%}$ & $\frac{237.1}{89.5}$ & $\frac{202.1}{76.3}$ & $\frac{255.7}{96.6}$ & $\underline{310.6}$ & - \\
\hline Wheat share in grain exports, $\%$ & - & - & - & 69.1 & 74.6 & 76.4 & 80.3 & 80.9 & 79.6 \\
\hline
\end{tabular}

*The table is compiled and calculated by the authors

Summarizing the results of analysis of the Russian grain complex development we can single out its global problem, which is the fact that it produces and exports products with low added value instead of processing these products and selling them with high added value. $[4,5]$

Wheat grain is a primary product for multipurpose use and is widely used in the national economy due to its nutritional value and rich chemical composition. Wheat grain contains proteins, fats, carbohydrates. Wheat contains up to $20 \%$ of protein, about $60 \%$ of carbohydrates, $1.5 \%$ of fats, essential oil, hemicellulose, fiber, starch, pectin, glucose, fructose, lactose, maltose, raffinose, vitamins - E, F, B1, B2, B6, C, PP, carotin, niacin, choline, biotin, folacin. There are also such macroand microelements as potassium, calcium, silicon, magnesium, sodium, sulphur, phosphorus, chlorine, aluminium, boron, vanadium, iron, iodine, cobalt, manganese, copper, molybdenum, nickel, tin, selenium, silver, strontium, titanium, chromium, zinc, zirconium in wheat. Wheat contains $3.4 \%$ of essential amino acids.

Wheat is used in many areas and industries, from the food sector to pharmacy and cosmetology. The tremendous value of wheat is determined by the fact that the products obtained from it serve as the main food products of the population. The food products obtained from it, in comparison with others the most demanded and cheap ones, are the products of mass and everyday consumption.

First of all, it is the main bakery crop. Baker's flour of 6 grades is obtained from wheat grain - they are extra grade, top grade, fine wheat flour, first grade, second grade, wholemeal flour, which are traditionally used for the production of bread. Wheat bread is distinguished by its palatability and is superior to bread made from other cereals flour in its nutritional value. Wheat used for flour production should contain a sufficient amount of protein $(10-20 \%)$. For the production of high-quality bread such important indicators of wheat grain baking capacity as gluten quantity (at least 23-25\%) and quality (at least I good quality group - 43.0-77.0 units of IDK) should be taken into account. The demand for wheat for the baker's flour production in the Russian Federation is 15 million tonnes per year. [6]

In addition, wheat flour is traditionally used for the confectionery, pasta, culinary products and flour national goods production. At present, the range of wheat flour products has expanded, for the production of which flour with certain properties that differ from the ones of the baker's flour is required.

For the pasta production, durum wheat is used, but also there high vitreous bread wheat (Triticum aestivum) can be used. Pasta made from Triticum aestivum is also popular in Russia and finds a market. Thus, for example, in Italy, which is the world trendsetter in the production of durum wheat and pasta, the latter can also be produced from Triticum aestivum, but such a product cannot be called "pasta".

Instant porridges are made from specially processed wheat flour, and high-protein breakfast flakes - from wheat gluten. 
Along with the main product of the milling industry, by-products are obtained - bran, wheat germ. Wheat bran is used as an additive in the production of bakery and flour confectionery goods, as well as like a biologically active additive to human food, which has recently gained high demand. Wheat bran is, first of all, an excellent source of fiber, a large amount of dietary fiber, which is very useful and important for digestion. Wheat germ has a high digestibility and biological value. It is the certain leader among natural sources of vitamin $\mathrm{E}$ and $\mathrm{B}$ vitamins and has excellent organoleptic characteristics (odorless, with a sweetish flavor, golden-yellow). [7]

Several types of groats are produced from wheat grains: semolina, wheat groats (Poltavskaya, "Artek"), burghul, couscous; they are used for cooking porridges, garnishes and also baked puddings, cheese pancakes, puddings, mousses, pilau, added to soups and sauces.

The use of grain wheat is not limited to the food sector. Wheat is widely used for fodder purposes and the compound feed production. According to experts, the share of wheat used for those purposes is up to $50 \%$. Wheat grain used for fodder purposes and the compound feed production should contain a sufficient amount of soluble protein and a reduced content of gluten (insoluble protein).

Wheat grain is the basic primary product in the distillery industry, from which beer, alcohol and vodka are produced.

Wheat is a crop with extraordinary useful properties, the application of which has opened up many possibilities for pharmacy and cosmetology. For cosmetic purposes, wheat germ oil is used, as it contains a rich mineralantioxidant complex. Wheat bran and crushed grain are included in many eco-scrubs and peels for sensitive and problem skin.

Earlier, monosodium glutamate enhancing the taste of food was obtained from wheat protein, now this substance is obtained mainly by chemical means. Considering that at present the population's demand for food products containing natural plant components is increasing, it is necessary to bring back the production of monosodium glutamate from wheat protein.

Products obtained from wheat grain have various consumer properties. For their production, wheat with different grain quality indicators is needed, therefore, the effective and rational use of wheat grain can be ensured by combining all stages of production and processing into a single manufacturing chain, in which the requirements for the final product should be established at the grain growing stage.

To this end, the All-Russian Scientific and Research Institute for Grain and Products of its Processing (VNIIZ) develops target standards for grain and its processed products. Currently, interstate standards are in force GOST 26574-2017 «Wheat bakery flour. Specifications», which establishes the requirements for wheat flour for baking, and GOST 34702-2020 «Wheat bakery. Specifications», which determines the requirements for bakery wheat. VNIIZ conducts scientific researches on the development of requirements for grain and flour for its intended purpose. The lack of requirements for flour for the intended purpose leads to the lack of relevant requirements for grain, which has already led to the absence of confectionery wheat (soft white wheat) growing. $[8,9]$

Based on the multifunctionality of wheat grain as a primary product, as well as on the understanding that the added value from its processing should remain on the territory of Russia, the economic efficiency of not only traditional processing, but, moreover, advanced processing of wheat grain becomes obvious.

As a result of advanced processing of wheat grain, a wide range of products with high added value can be obtained which are native and modified starches, gluten, glucose-fructose syrups (HFSS), starch syrups, organic acids, food-grade alcohol, biofuel and other products. At further processing of the obtained starch, a wide range of various derivatives and biobased products is produced, the application of which is practically unlimited - from the food industry to the petrochemical one. [10]

A paradoxical situation has developed: Russia is the world's largest exporter of grain, and is acutely dependent on imported products of its processing (considerable amounts of amino acids and vitamins are almost $100 \%$ imported from abroad). The necessity for advanced processing of grain is determined by the «Long-term strategy for the development of the grain complex of the Russian Federation until 2035».

The Strategy is based on the system approach to increasing wheat grain production and improving its quality. In terms of the strategic outlook, the system of measures involves [6]:

- $\quad$ stimulation of the production of Triticum durum and Triticum aestivum with high quality indicators;

- $\quad$ the promotion of positions of Russian wheat on the world market will be greatly determined by its quality. This will require a rational combination of using natural competitive advantages, innovative and investment factors, in particular, the creation of specialized zones for the production of high-quality wheat varieties and the formation of grain clusters in the regions;

- $\quad$ increasing the yield and quality of grain by maintaining a healthy phytosanitary environment;

- $\quad$ providing with agricultural machinery in order to optimize the timing of agritechnological activities (by 2035, 1 tractor will be charged for 156 ha of arable land and 1 combine harvester - for 278 ha of cultivated area);

- $\quad$ increasing domestic consumption through the processing of wheat grain, including the creation of advanced grain processing capacities. The Strategy proposes to channel investments in the amount of 150 billion rubles for these purposes.

\section{Conclusion}

In general, the studies conducted allow us to draw the following conclusions:

1. Wheat grain is a very valuable primary product, from which a wide range of products with high added value is obtained. 
2. There are certain problems in the development of the grain complex of Russia, including wheat. In recent years, an emphasis is placed on the development of grain export at the expense of its processing and the development of its domestic consumption. Therefore, there is an acute dependence on imports of certain wheat processing products.

3. The outlook for the wheat grain production is associated with the expansion of not only traditional, but also advanced processing of wheat grain.

\section{References}

1. Russian statistical yearbook 2002-2019 URL: https://www.gks.ru/folder/210/document/12994 (accessed date: 02.06.2021).

2. Agriculture, hunting, forestry of Russia 1990-2020 URL: https://rosstat.gov.ru/enterprise_economy?print=1 (accessed date: 02.06.2021).

3. News of agricultural market and agriculture - Major interest: Russia may be in advance of Turkey in sales of cereals and flour. URL: https://agrobook.ru/blog/user/inga/krupnyy-interesrossiya-mozhet-obognat-turciyu-po-prodazhamkrup-i-muki (accessed date: 02.06.2021)

4. Meleshkina E.P., Bundina O.I., Khuhrin A.S. Sustainable grain complex development of russia: formation of grain clusters. E3S Web of Conferences "International Scientific and Practical Conference "Fundamental and Applied Research in Biology and Agriculture: Current Issues, Achievements and Innovations", FARBA 2021, February 24-25, 2021, Orel, Russia. (2021).

5. Altukhov A.I., Kundius V.A., Kovaleva I.V. Prospects of development of export of agricultural products and foodstuffs in the countries of the shanghai cooperation organization: IOP Conference Series: Earth and Environmental Science. The proceedings of the conference AgroCON-2019. April 18-19, Kurgan, Russia. P. 012201. (2019)

6. Long-term strategy for the development of the grain complex of the Russian Federation until 2035. URL:

http://static.government.ru/media/files/ylIpA0ZfzdMCf ATNBKGff1cXEQ142yAx.pdf (accessed date: 15.05.2021).

7. T.V. Alekseeva, N.N. Popova, M.I. Korystin, Food industry. 11. P. 36-37. (2010).

8. E.P. Meleshkina, Agrarian Reporter of South-East. 3. P. 4-7. (2009).

9. E.P. Meleshkina Russian wheat grain quality: dynamics, features and problems. Modern methods, means and standards in the field of grain and grain products quality assessment: Collected articles of the $13^{\text {th }}$ All-Russian scientific and practical conference. June 6-10, 2016, Anapa, Russia. P. 4-9. (2016).

10. V.G. Goldshtein, D.S. Kulikov, S.A. Strahova. Food industry.7. P. 14-19. (2018). 